\title{
TRANSACTIONS OF \\ THE ROYAL SOCIETY OF EDINBURGH
}

\section{VOLUME 69, 1973-74}

3. The Cytology of the Parthenogenetic Australian Weevil Listroderes costirostris Schönh. By Ann R. Sanderson, Department of Biological Sciences, University of Dundee. (With 7 plates and 1 table.)

(Issued June 6, 1973.)

4. On the Structure of a Petrified Stem and some Associated Seeds from the Lower Carboniferous Rocks of East Lothian, Scotland. By P. D. W. Barnard and A. G. Long. (With 4 plates and 5 text-figures.)

(Issued June 8, 1973.)

5. Additional Cytotaxonomic Notes on the Pteridophytes of Jamaica. By Trevor G. Walker, B.Sc., Ph.D., F.L.S. (With 10 text-figures and 5 tables.)

(Issued October 29, 1973.)

6. A Re-examination of the Central Nervous System of Alderia modesta (Lovén). By T. Gascoigne, Alleyn's School, Dulwich, London. Communicated by Sir Maurice Yonge, C.B.E., F.R.S. (With 6 text-figures.)

(Issued January 31, 1974.)

7. Coral Reefs and Molluscs. By C. M. Yonge, P.R.S.E., Department of Zoology, University of Edinburgh. (With 3 plates and 10 text-figures.)

(Issued February 26, 1974.)

8. A Stratigraph cal Revision of the Old Red Sandstone of North-eastern Caithness. By R. Nowell Donovan, Richard J. Foster and T. Stanley Westoll, F.R.S. (With 7 text-figures and 11 tables.)

(Issued March 28, 1974.)

9. On the Ecology and Sedimentation of the Cardium Shellsands and Transgressive Shellbanks of Traigh Mhor, Island of Barra, Outer Hebrides. By George E. Farrow. (With 8 plates, 19 text-figures and 2 tables.)

(Issued November 7, 1974.)

10. Triradioxylon-a New Genus of Lower Carboniferous Petrified Stems and Petioles together with a Review of the classification of Early Pterophytina. By P. D. W. Barnard and A. G. Long. (With 4 plates and 3 text-figures.)

(Issued March 21, 1975.)

11. Some Observations on the Fertile Parts of Zosterophyllum myretonianum Penhallow from the Lower Old Red Sandstone of Scotland. By Dianne Edwards. (With 2 plates and 2 text-figures.)

(Issued March 14, 1975.)

12. Further Observations on some Lower Carboniferous Seeds and Cupules. By A. G. Long. (With 6 plates, 6 text-figures and 7 tables.)

(Issued May 16, 1975.)

Fellows of the Society purchasing publications for their own use will be allowed a special discount of $33 \frac{1}{3}$ per cent on the current prices (see Law XVI).

Printed in Scotland

by $T$. and A. Constable Ltd., Hopetoun Street, Edinburgh EH7 4 NF 